\title{
OPEN Low oxygen levels caused by Noctiluca scintillans bloom kills corals in Gulf of Mannar, India
}

\author{
K. Diraviya Raj ${ }^{1 凶}$, G. Mathews ${ }^{1}$, David O. Obura ${ }^{2}$, R. L. Laju ${ }^{1}$, M. Selva Bharath ${ }^{1}$, \\ P. Dinesh Kumar ${ }^{1}$, A. Arasamuthu' ${ }^{1}$, T. K. Ashok Kumar ${ }^{3}$ \& J. K. Patterson Edward ${ }^{1}$
}

Coral reefs around the world are undergoing severe decline in the past few decades. Mass coral mortalities have predominantly been reported to be caused by coral bleaching or disease outbreaks. Temporary hypoxic conditions caused by algal blooms can trigger mass coral mortalities though are reported rarely. In this study in Gulf of Mannar (GoM), southeast India, we report a significant coral mortality caused by a bloom of the ciguatoxic dinoflagellate Noctiluca scintillans during SeptemberOctober 2019. Dissolved oxygen levels declined below $2 \mathrm{mg} \mathrm{l}^{-1}$ during the bloom causing temporary hypoxia and mortality (up to $71.23 \%$ ) in the fast growing coral genera Acropora, Montipora and Pocillopora. Due to global climate change, more frequent and larger algal blooms are likely in the future. Hence, it is likely that shallow water coral reefs will be affected more frequently by episodic hypoxic conditions driven by algal blooms. More studies are, however, required to understand the mechanism of coral mortality due to algal blooms, impacts on community composition and the potential for subsequent recovery.

Dissolved oxygen levels in the oceans and coastal waters around the world have been reported to be declining, and coastal ecosystems including coral reefs are affected by this ${ }^{1,2}$. Increased nutrient inputs and warming waters combine to reduce the oxygen levels in global waters ${ }^{2}$. Coral reefs around the world are undergoing severe decline mainly due to issues related to climate such as mass bleaching, ocean acidification and ocean deoxygenation ${ }^{3-5}$. Ocean deoxygenation in particular has increasingly received attention in the context of global coral reef health in recent years ${ }^{5-7}$. In addition to global ocean climate stressors, localised hypoxic events driven by e.g. eutrophication also have the capacity to impact coral communities ${ }^{1,8,9}$. Hypoxia in the marine ecosystem describes a condition of low dissolved oxygen levels that may affect marine organisms by altering behavioural and physiological responses, reducing growth rates and fecundity and, if prolonged or severe, may lead to mortality ${ }^{5,10}$. Ecological processes in a reef ecosystem such as productivity, respiration, reproduction, calcification, bleaching, eutrophication, acidification and space-competition are related to oxygen levels and can be affected by hypoxic conditions ${ }^{7}$. Recent studies underline the severity of hypoxic conditions in the water column and their impact on corals ${ }^{1,11}$.

Temporary hypoxic conditions caused by algal blooms can result in reef-building coral mortality, but are reported rarely ${ }^{12,13}$. Climate change has been linked to increased frequencies of algal blooms in recent years ${ }^{14}$. Frequency of algal blooms, especially of Noctiluca scintillans, has increased significantly in the Indian Ocean and in Indian waters during the past few decades ${ }^{15,16}$. Blooms of $N$. scintillans can be of two forms that are red or green tides; red is heterotrophic while green has a photosynthetic symbiont Pedinomonas noctilucae $e^{17}$. While red tides of $N$. scintillans have been reported to be harmful, green tides have been termed as harmless though they cause low dissolved oxygen levels ${ }^{18}$.

The Gulf of Mannar (GoM) in southeast India is one of the four major coral reef areas of India that provides direct livelihood to thousands of dependent fishermen. GoM has a chain of 21 uninhabited islands between Tuticorin and Rameswaram around which coral reefs mainly occur. Corals of GoM have been disturbed significantly by climate change implications and localised anthropogenic impacts ${ }^{19,20}$. Blooms of $N$. scintillans causing a green tide were witnessed in GoM during September 2019 when thousands of fishes and other organisms were found dead along the shore in the Mandapam region. Previously, algal blooms were not considered a significant threat to corals of GoM, though minimal impact was observed on corals due to a similar bloom in $2008^{12}$. The present study reports the impact of the September 2019 bloom of N. scintillans on corals of GoM.

${ }^{1}$ Suganthi Devadason Marine Research Institute, 44-Beach Road, Tuticorin 628001, Tamil Nadu, India. ${ }^{2}$ CORDIO East Africa, P.O. Box 10135, Mombasa 80101, Kenya. ${ }^{3}$ Gulf of Mannar Marine National Park, Ramanathapuram 623 503, India. ${ }^{\boxplus}$ email: diraviyam_raj@yahoo.co.in 


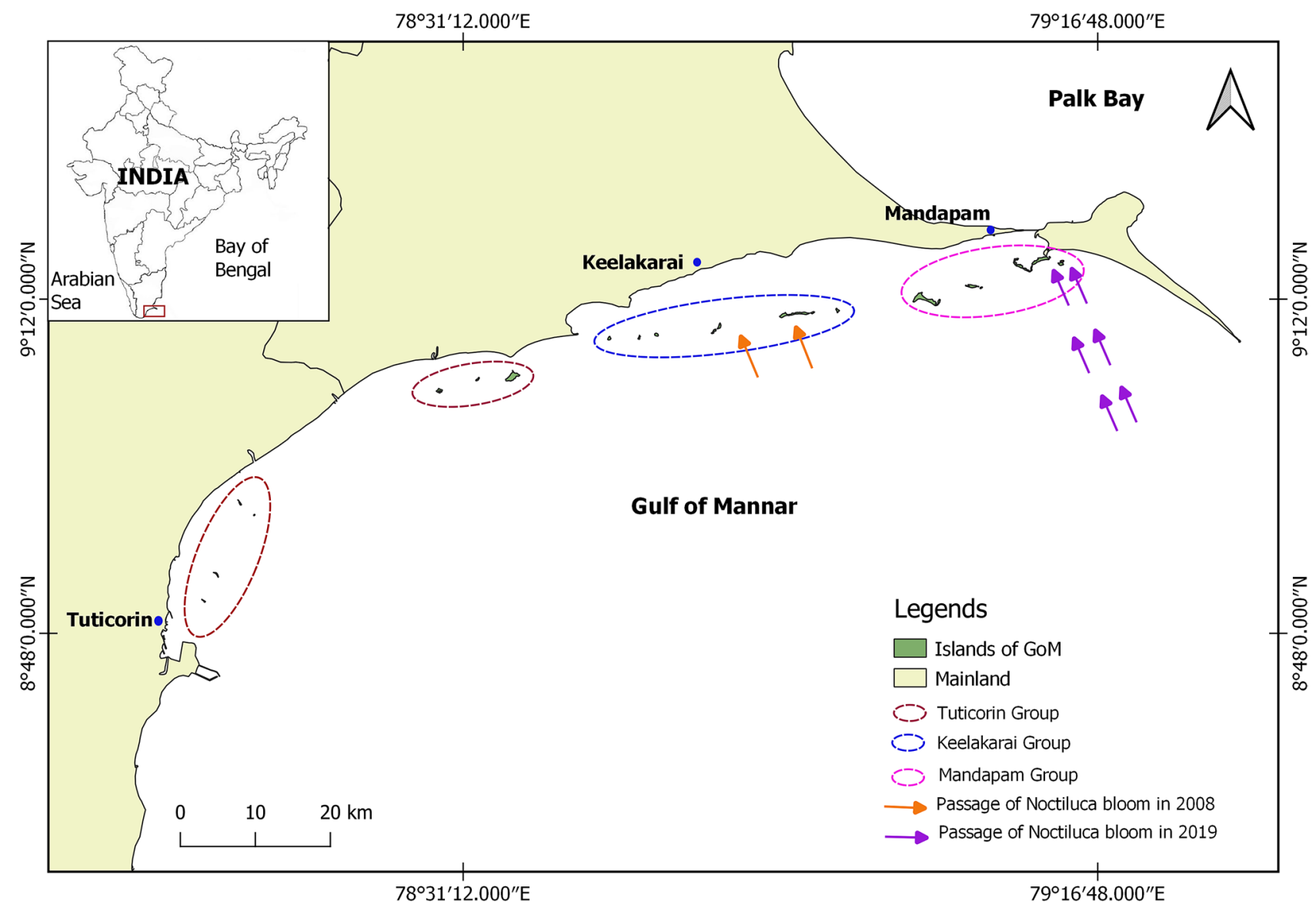

Figure 1. Map showing islands of the Gulf of Mannar and passage of the Noctiluca scintillans bloom; Base map was prepared by digitizing the georeferred Toposheet of Survey of India (http://www.surveyofindia.gov.in/) and field data using Open source GIS software (QGIS 3.10.6; https://qgis.org/en/site/forusers/download.html).

\section{Materials and methods}

Preliminary assessment. The 21 islands of GoM are in three groups with seven islands each, the Mandapam, Keelakarai and Tuticorin groups (Fig. 1). Bloom of N. scintillans had affected Keelakarai region of GoM in $2008^{12}$. On 12th September 2019, a large drifting bloom of N. scintillans was found to have killed thousands of fishes along the shore between Kundukal and Vedalai (Approximately $17 \mathrm{~km}$ coastal distance) in the Mandapam region (Fig. S1). A rapid underwater visual assessment was done from 14 to 18th of September 2019 to find out the possible impact of the bloom on corals in the Mandapam group of islands, namely Shingle, Krusadai, Pullivasal, Poomarichan, Manoliputti, Manoli and Hare. SCUBA dives were made at arbitrary locations around these islands to do visual inspection of corals to document the possible bleaching and mortality. This preliminary assessment confirmed impact of the bloom at two islands, Shingle and Krusadai. The area of impact was delineated and measured with GPS tracking and the data were transferred into QGIS (Quantum GIS) open source software.

Detailed assessment. Twenty meter $(20 \mathrm{X} 2 \mathrm{~m})$ belt transects were laid to assess the prevalence of affected coral colonies in the affected areas of Shingle and Krusadai Islands on 17th and 27th September and 04th October 2019. Ten belt transects $(20 \mathrm{X} 2 \mathrm{~m})$ were laid at the impacted areas in Shingle Island and five at Krusadai Island with a minimum distance of $10 \mathrm{~m}$ between transects. Colony counts were made to assess the prevalence of affected colonies within the $40 \mathrm{~m}^{2}$ area of each transect. On each sampling visit, the same number of transects were laid at each island, but transect placement was arbitrary each time within the affected area. Samples of $N$. scintillans cells were collected from the surface water by towing a plankton net number 30 of mesh size $60 \mu \mathrm{m}$ for half an hour and the concentration density was measured using a Sedwick Rafter counting chamber.

Water samples were collected from the affected areas each time and dissolved oxygen content was measured using Winkler's titration method following Strickland and Parsons ${ }^{21}$. The depth of the reef was very shallow $(<3)$ and coral growth was up to $1 \mathrm{~m}$ above the bottom. To measure the dissolved oxygen content, triplicate water samples were collected in $125 \mathrm{ml}$ BOD bottles with glass stoppers just above the coral colonies (1-2 $\mathrm{m}$ depth) by diving, between 8 and 9 AM in the morning. Samples were immediately brought to the boat for immediate fixing with $1 \mathrm{ml}$ of manganous chloride and $1 \mathrm{ml}$ of alkaline iodide, and shaken vigourously to stimulate precipitation. $1 \mathrm{ml}$ of concentrated sulfuric acid was then added to dissolve the precipitate before the titration, ensuring no 


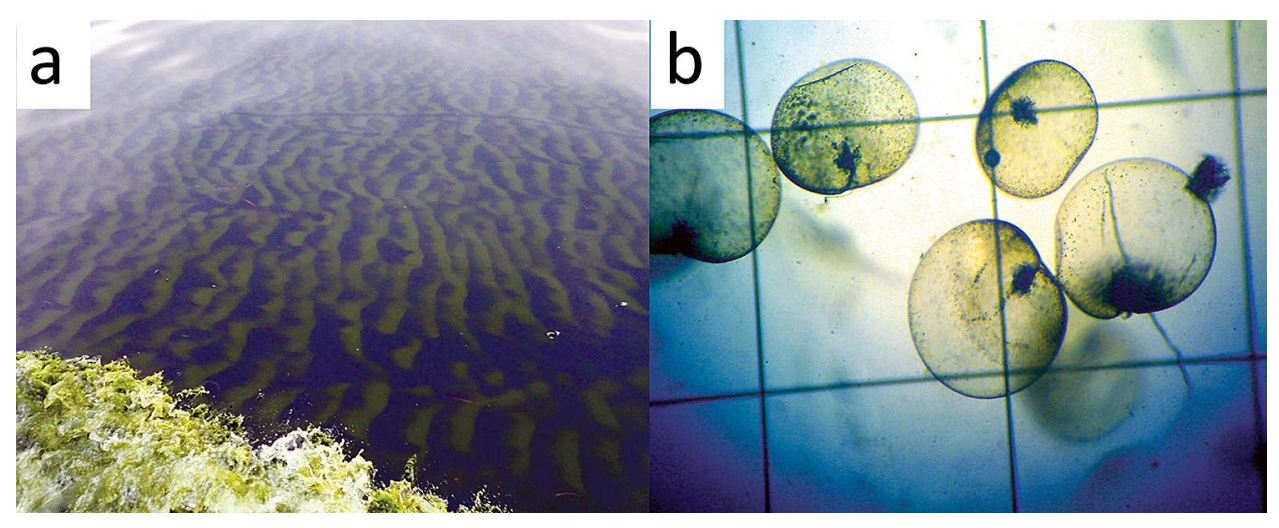

Figure 2. (a) Green tide of Noctiluca scintillans in the Gulf of Mannar; (b) image of N.scintillans cells; size of the grid is $1 \mathrm{~mm}^{2}$ (N. scintillans exhibits bioluminescence when disturbed).

air bubbles were trapped inside. Fixed samples were kept inside a dark box until titration. Titration of the fixed samples was done with sodium thiosulfate and starch solution as an indicator, within two hours of collection. Study islands are very close to the shore and hence the analysis could be done within two hours in the field centre.

Water samples were collected at the same depth to measure temperature, salinity, pH and TDS (Total Dissolved Solids) in a sterile plastic container. Water temperature was measured using a digital thermometer and salinity was measure using a handheld refractometer. $\mathrm{pH}$ and TDS were measured in the field using a handheld water proof tester Hanna HI98129. All these parameters were measured immediately on the boat.

\section{Results and discussion}

Though the time and place of the origin of this bloom is unknown, the presumable causes of it were high temperatures, abundant nutrients, low tidal amplitude, and little current. According to fishermen, these bioluminescent blooms were first seen about 15 nautical miles offshore of the Mandapam coast between India and Sri Lanka on 6th September, and subsequently moved towards the shore (Fig. 2). Bloom of N. scintillans in 2008 was reported to affect all the marine organisms including corals in $\mathrm{GoM}^{12}$. On 14th September, our preliminary assessment revealed that corals in Shingle and Krusadai islands were possibly affected by the bloom. A great multitude of $N$. scintillans cells were found settled on corals and other benthic organisms in the affected areas. A greenish settlement was observable on live coral colonies and other benthic organisms including macro algae, coralline algae and sponges etc.(Fig. S2). Settling of N. scintillans on benthic organisms has been reported to cause significant damage to the reef organisms through asphyxiation ${ }^{12}$. At Shingle Island, the area of significant impact was about 8.1 hectares on the shoreward side of the Island $\left(79^{\circ} 14^{\prime} 14.38^{\prime \prime} \mathrm{E}, 9^{\circ} 14^{\prime} 44.23^{\prime \prime} \mathrm{N}\right)$ at depths between 1 and $3 \mathrm{~m}$ (Fig. 3). At Krusadai Island, an area of 2.1 hectares in the shoreward side was found affected by the bloom $\left(79^{\circ} 13^{\prime} 20.78^{\prime \prime} \mathrm{E}, 9^{\circ} 15^{\prime} 00.88^{\prime \prime} \mathrm{N}\right)$ at depths between 1 and $2 \mathrm{~m}$. The rest of the reef areas in both of these islands were healthy without any impact. The settled cells of $N$. scintillans were found to be washed ashore during subsequent surveys. In addition to dead fishes, a multitude of benthic communities such as crustaceans, mollusks and echinoderms were also found dead on the bottom in the impacted areas. Surveys between 15 and 18th September 2019 confirmed that corals in other islands (Pullivasal, Poomarichan, Manoliputti, Manoli and Hare) were in good health, and without any noticeable impact due to the bloom. Shingle and Krusadai islands occur closest to the mainland, and the concentrated bloom appeared to get trapped by currents between the mainland shore and islands.

On 14th September, coral mortality was not observed in the affected areas though the colonies were observed to be disturbed by the settling $N$. scintillans cells. Low dissolved oxygen levels have been reported to be the primary cause of benthic mortality during algal blooms ${ }^{22}$. Dissolved oxygen levels were $1.48 \mathrm{mg} \mathrm{l}^{-1}$ at Shingle Island and $2.02 \mathrm{mg} \mathrm{l}^{-1}$ at Krusadai Island in the affected areas. This compares to 'normal' levels for coral reefs of 5-8 $\mathrm{mg} \mathrm{l}^{-1}$, and Haas et al. ${ }^{11}$ found that dissolved oxygen content less than $4 \mathrm{mg} \mathrm{l}^{-1}$ is detrimental to acroporid corals. Moreover, branching coral forms have been reported to be more susceptible to hypoxic episodes than spherical or massive form $s^{5}$. Corals are routinely exposed to fluctuations in oxygen levels at the tissue level due to photosynthesis and respiration processes of endosymbionts ${ }^{7}$, but are negatively impacted when (sub-) lethal thresholds of hypoxia exposure are exceeded ${ }^{1,5,11}$. Lethal hypoxia thresholds appear to differ considerably

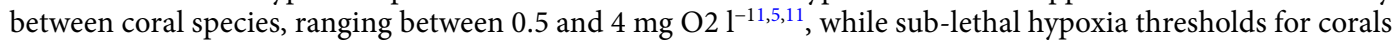
are almost entirely unknown ${ }^{5}$.

Seawater temperature can significantly impact dissolved oxygen levels ${ }^{23,24}$. Water temperature was 29.9 and $29.8^{\circ} \mathrm{C}$ (Table 1) at Shingle and Krusadai islands respectively and these levels are marginally higher than the normal levels for this particular time of the year. Apart from the summer months (April to June), temperature levels in GoM do not go higher than $29^{\circ} \mathrm{C}^{20}$. The concentration of $N$. scintillans was $43.4 \times 10^{5}$ and $27.3 \times 10^{5}$ cells $\mathrm{l}^{-1}$ at Shingle and Krusadai Islands respectively; $\mathrm{pH}$ and TDS were also high in the affected area (Table 1). Dissolved oxygen levels in other sites of these two islands and in other five islands were higher than $5 \mathrm{mg} \mathrm{l}^{-1}$.

During the next assessment on 17th of September 2019, severe coral mortality was observed at the affected sites. At Shingle Island, overall coral colony density was $134.25(\mathrm{SE} \pm 3.28)$ no. $100 \mathrm{~m}^{-2}(\mathrm{n}=537)$ within ten $20 \mathrm{~m}$ 


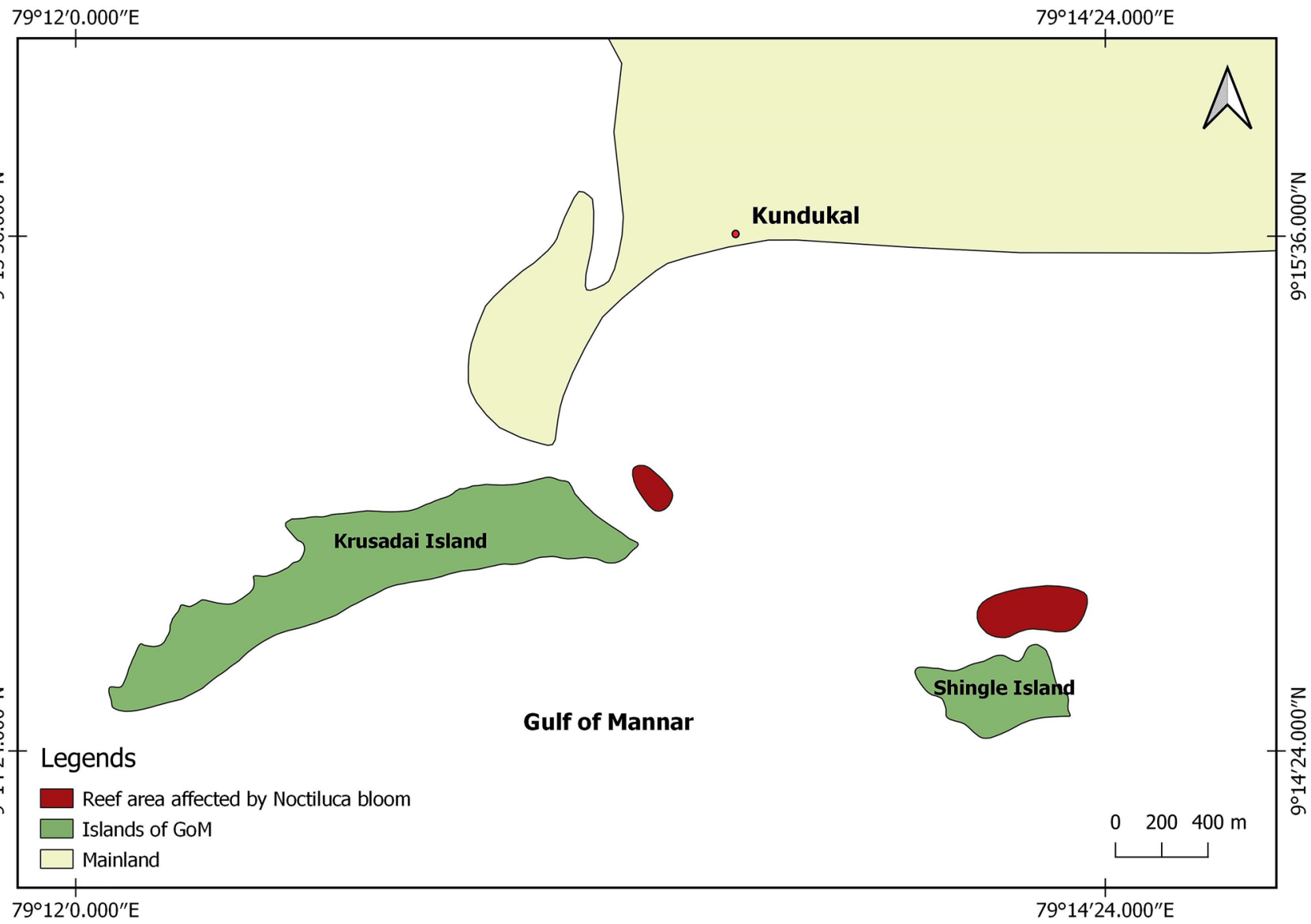

Figure 3. Map showing the affected islands in the Mandapam group shown in Fig. 1. Base map was prepared by digitizing the georeferred Toposheet of Survey of India (http://www.surveyofindia.gov.in/) and field data using Open source GIS software (QGIS 3.10.6; https://qgis.org/en/site/forusers/download.html).

\begin{tabular}{|c|c|c|c|c|c|c|}
\hline Date & $\begin{array}{l}\begin{array}{l}\text { Noctiluca scintillans density } \\
\left(\text { cells } 1^{-1} \text { ) }\right.\end{array} \\
\end{array}$ & $\begin{array}{l}\text { Dissolved Oxygen content (mg } \\
\left.\mathrm{l}^{-1}\right)\end{array}$ & Temperature $\left({ }^{\circ} \mathrm{C}\right)$ & Salinity (PPT) & pH & $\begin{array}{l}\text { TDS (Total Dissolved Solids) } \\
(\mathrm{g} / \mathrm{l})\end{array}$ \\
\hline \multicolumn{7}{|l|}{ Shingle Island } \\
\hline 14th September 2019 & $43.4 \times 10^{5}$ & 1.48 & 29.9 & 33.2 & 7.08 & 51.44 \\
\hline 17th September 2019 & $1.63 \times 10^{3}$ & 3.78 & 28.4 & 34.2 & 8.05 & 46.96 \\
\hline 27th September 2019 & Nil & 6.02 & 29.5 & 34.8 & 8.24 & 28.62 \\
\hline 4th October 2019 & Nil & 7.13 & 28.8 & 35 & 7.13 & 27.54 \\
\hline \multicolumn{7}{|l|}{ Krusadai Island } \\
\hline 14th September 2019 & $27.3 \times 10^{5}$ & 2.02 & 29.8 & 33.4 & 7.12 & 49.5 \\
\hline 17th September 2019 & $0.88 \times 10^{3}$ & 3.39 & 28.5 & 34.2 & 8.1 & 49.34 \\
\hline 27th September 2019 & Nil & 5.73 & 29.6 & 34.5 & 8.32 & 19.14 \\
\hline 4th October 2019 & Nil & 7.24 & 28.6 & 35.1 & 7.24 & 30.89 \\
\hline
\end{tabular}

Table 1. Environmental characterization at the affected sites in Shingle and Krusadai Islands.

belt transects which is dominated by Acropora (64\%) followed by Montipora (15\%). Out of total 537 colonies, $33.52 \%(\mathrm{n}=180)$ were found dead (Fig. 4), which include $34.5(\mathrm{SE} \pm 1.05)$ no. $100 \mathrm{~m}^{-2}(\mathrm{n}=138)$ of Acropora, $7.75(\mathrm{SE} \pm 0.75)$ no. $100 \mathrm{~m}^{-2}(\mathrm{n}=31)$ of Montipora and $2.75(\mathrm{SE} \pm 0.35)$ no. $100 \mathrm{~m}^{-2}(\mathrm{n}=11)$ of Pocillopora. The death of coral colonies was so rapid that the coral tissue was intact on the colony surface and still had its natural colour (Fig. 5). When wafted with water by hand or with scuba air, the tissue peeled off exposing the skeleton (Supplementary video). Other observed genera such as Dipsastraea, Favites, Porites, Hydnophora, Goniastrea, Echinopora, Turbinaria, Platygyra, Goniopora and Symphyllia in the same site were all alive (Fig. S3), though with excess mucus production. This may be explained by differential lethal thresholds for oxygen levels at species and growth form levels ${ }^{5,19}$. At Krusadai Island, the overall coral density on 17th September was 66 (SE \pm 2.54 ) no. $100 \mathrm{~m}^{-2}(\mathrm{n}=132)$, dominated by Acropora. Among the counted colonies, 6 (SE \pm 1.03$)$ no. $100 \mathrm{~m}^{-2}$ of Acropora 


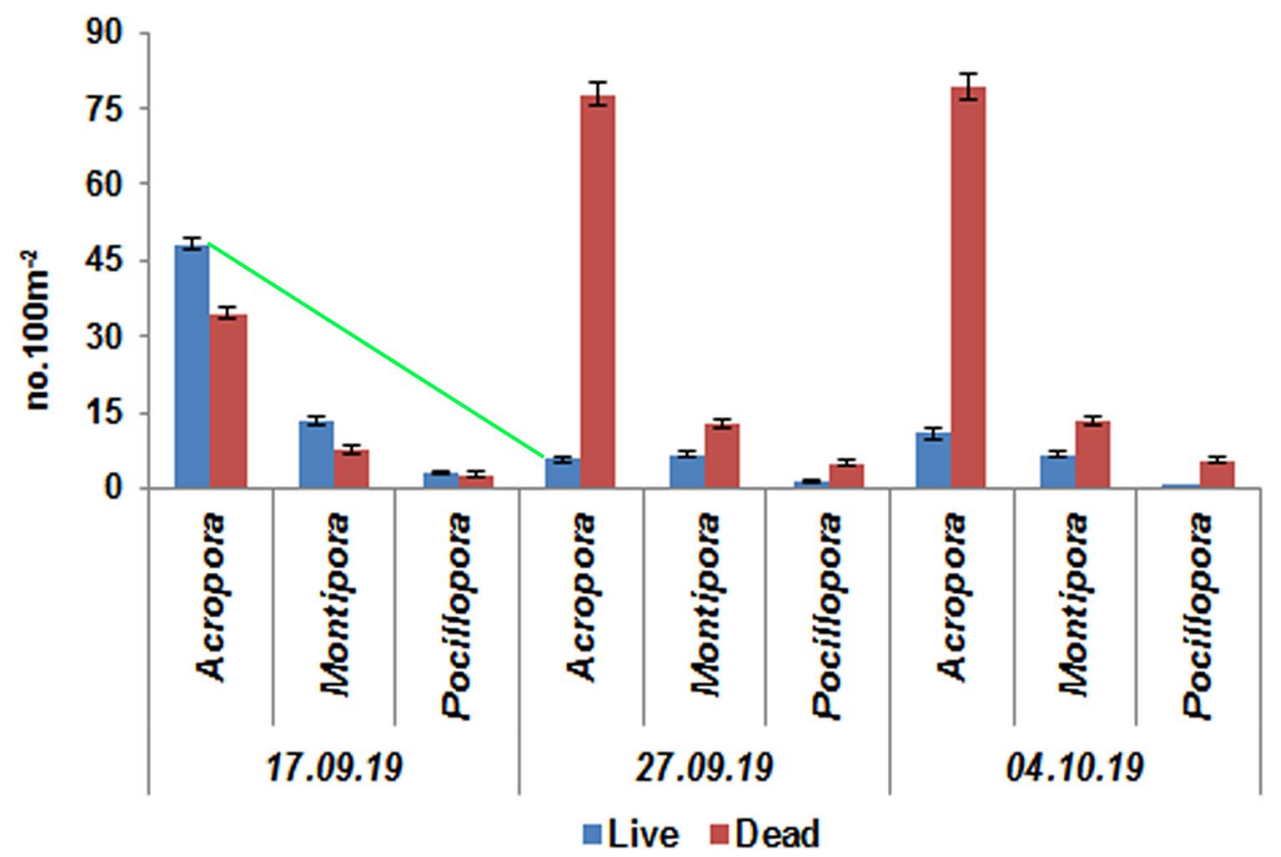

Figure 4. Density of live and dead colonies of affected coral genera (Acropora, Montipora and Pocillopora) in Shingle Island, by date; the green line indicates the drastic decline of Acropora density between 17.09.2019 and 27.09.2019.

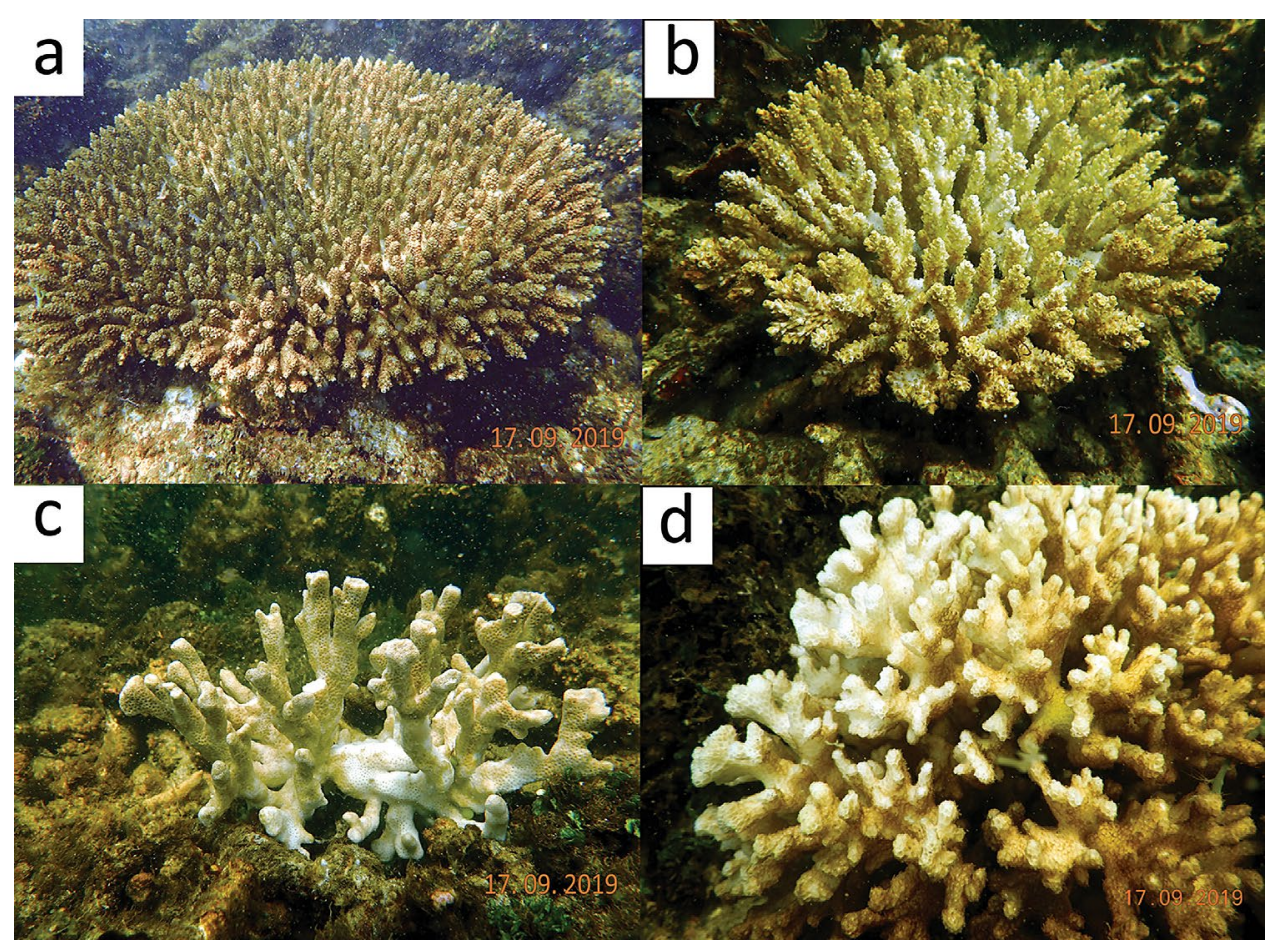

Figure 5. Rapid mortality of corals presumably due to low oxygen levels caused by Noctiluca scintillans; (a, b) Acropora; (c) Montipora; (d) Pocillopora.

were found recently dead while mortality was not observed in other available genera such as Montipora, Pocillopora, Dipsastraea, Favites, Porites and Turbinaria. Dissolved oxygen levels had increased to $3.78 \mathrm{mg}^{-1}$ at Shingle Island and to $4.02 \mathrm{mg} \mathrm{l}^{-1}$ at Krusadai Island at the affected sites and the water had started to become clear. The

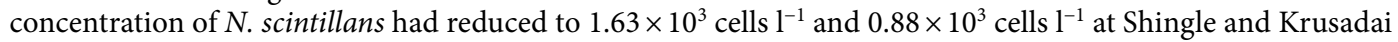
Islands, respectively (Table 1). 
Assessment on 27th September 2019 at the impacted area in Shingle Island, showed that the overall density of coral colonies within ten $20 \mathrm{~m}$ transects was $135.75(\mathrm{SE} \pm 2.82)$ no. $100 \mathrm{~m}^{-2}(\mathrm{n}=543)$ and of them $70.35 \%(\mathrm{n}=382)$ of colonies belonging to Acropora, Montipora and Pocillopora were found dead revealing that the impact of algal bloom was more severe than expected (Fig. 4). It was almost two weeks since the corals had died and hence secondary algae had started colonizing the dead colonies. On the same day at the impacted area of Krusadai Island, overall coral density within five belt transects was 65.5 (SE \pm 1.83$)$ no.100 $\mathrm{m}^{-2}(\mathrm{n}=131)$, of which $9.09 \%$ $(\mathrm{n}=12)$ of colonies belonging to Acropora were found dead. By 27 th September, dissolved oxygen levels had increased to 6.02 and $5.73 \mathrm{mg} \mathrm{l}^{-1}$ respectively at the affected areas of Shingle and Krusadai islands (Table 1). N. scintillans cells were absent in all the sites indicating the end of bloom. On 04th October 2019, the overall coral colony density within $20 \mathrm{~m}$ belt transects was $138(\mathrm{SE} \pm 2.08)$ no.100 $\mathrm{m}^{-2}(\mathrm{n}=552)$ and of them $71.23 \%(\mathrm{n}=393)$ colonies belonging to Acropora, Montipora and Pocillopora were found dead at the area of impact in Shingle Island (Fig. 4). No further mortality was witnessed in the affected area of Krusadai Island. Secondary algae have completely overgrown the dead coral colonies making the reef look green (Fig. S4). Dissolved oxygen levels were reasonably high at 7.13 and $7.24 \mathrm{mg} \mathrm{l}^{-1}$ respectively at Shingle and Krusadai Islands during this time (Table 1).

Coral mortality due to algal bloom and consequent hypoxia has rarely been reported ${ }^{12,13,25}$. The present study reports that the impact of blooms can be severe on corals. Different coral species respond differently to low oxygen levels according to their respiration and photosynthesis ${ }^{5,26}$. Thus, low oxygen levels can orchestrate the coral mortality by affecting coral's productivity and respiration ${ }^{7}$. Further, fast growing corals such as Acropora and Pocillopora have been reported to be more susceptible to low oxygen levels ${ }^{11,13,27}$. Fast growing coral species have faster metabolism rates ${ }^{28}$ and hence metabolic oxygen requirements are higher ${ }^{11,29}$. Thus, the mortality of fast growing species in the present study was presumably due to the low oxygen levels induced by N.scintillans bloom.

Bleaching episodes in 2010 and 2016 had also caused significant mortality to these fast growing species in $\mathrm{GoM}^{19,20}$. Corals in GoM start to bleach when water temperature exceeds $30^{\circ} \mathrm{C}$ and the temperature levels during this bloom period ranged between 28.4 and $29.9^{\circ} \mathrm{C}$. Though bleaching was not observed, heat stress might also have played its role in coral mortality along with low oxygen levels as the temperature level almost reached $30^{\circ}$ C. Similar temperature levels were reported during the bloom of $N$. scintillans in 2008 in $\mathrm{GoM}^{12}$.

Corals in Gulf of Mannnar are still recovering from the 2016 bleaching episode ${ }^{20}$ and hence the present decline is significant. Phase shifts on coral reefs are predominantly associated with shifts from hard coral-dominated communities to macroalgae-dominated ones ${ }^{30}$. Space competition between corals and other organisms such as algae and sponges has been reported to negatively impact the corals of GoM after the 2016 bleaching event ${ }^{20,31}$. At present, secondary algae have completely occupied the dead coral colonies, which will affect the coral recovery by hindering the attachment of new coral recruits during the next spawning season ${ }^{32}$. Recent studies suggest hypoxia increases coral susceptibility to bleaching ${ }^{27}$, and may increase disease prevalence and algal proliferation ${ }^{7}$. Thus algal blooms add to the existing array of threats to corals of GoM that needs to be understood more with further focused research.

On account of the problems related to climate change, there has been a steady and severe decline of coral reefs in the past two decades. Bleaching and diseases have been reported to cause mass coral mortalities within a very short time. The observations of the present study alert us to possible mass mortality due to short-term hypoxic condition caused by algal blooms. Algal blooms and hypoxic conditions are predicted to occur more frequently in the future due to climate change ${ }^{14}$. Hence, it is likely that shallow water coral reefs will be affected more frequently by temporary low oxygen levels caused by algal blooms. More studies are, however, required to understand the mechanism of coral mortality due to algal blooms, impacts on community composition and the potential for subsequent recovery.

Received: 8 July 2020; Accepted: 4 December 2020

Published online: 17 December 2020

\section{References}

1. Altieri, A. H. et al. Tropical dead zones and mass mortalities on coral reefs. Natl. Acad. Sci. 114, 3660-3665 (2017).

2. Breitburg, D. et al. Declining oxygen in the global ocean and coastal waters. Science eaam359, 7240. https://doi.org/10.1126/scien ce.aam7240 (2018).

3. Hoegh-Guldberg, O. et al. Coral reefs under rapid climate change and ocean acidification. Science 318, 1737-1742 (2007).

4. Pandolfi, J. M., Connolly, S. R., Marshall, D. J. \& Cohen, A. L. Projecting coral reef futures under global warming and ocean acidification. Science 333, 418-422 (2011).

5. Hughes, D. J. et al. Coral reef survival under accelerating ocean deoxygenation. Nat. Clim. Change 10, 296-307 (2020).

6. Altieri, A. H. \& Gedan, K. B. Climate change and dead zones. Glob. Change Biol. 21, 1395-1406 (2015).

7. Nelson, H. R. \& Altieri, A. H. Oxygen: the universal currency on coral reefs. Coral Reefs 38, 177-198 (2019).

8. Le Hénaff, M. et al. Coral mortality event in the Flower Garden Banks of the Gulf of Mexico in July 2016: local hypoxia due to cross-shelf transport of coastal flood waters?. Cont. Shelf Res. 190, 103988 (2019).

9. Kealoha, A. K. et al. Localized hypoxia may have caused coral reef mortality at the Flower Garden Banks. Coral Reefs 39, 119-132 (2020).

10. Rabalais, N. N. et al. Dynamics and distribution of natural and human-caused hypoxia. Biogeosciences 7, 585 (2010).

11. Haas, A. F., Smith, J. E., Thompson, M. \& Deheyn, D. D. Effects of reduced dissolved oxygen concentrations on physiology and fluorescence of hermatypic corals and benthic algae. PeerJ 2, e235. https://doi.org/10.7717/peerj.235 (2014).

12. Gopakumar, G., Sulochanan, B. \& Venkatesan, V. Bloom of Noctiluca scintillans (Macartney) in Gulf of Mannar, southeast coast of India. J. Mar. Biol. Assoc. India 1, 75-80 (2009).

13. Montoya-Maya, P. H. Algal bloom: Transplanted corals fight back. Nature Seychelles Reef Rescuers Project. http://www.seychelles weekly.com/November\%2026,\%202015/environ1_algal_bloom_reefs.html (2015)

14. Griffith, A. W. \& Gobler, C. J. Harmful algal blooms: a climate change co-stressor in marine and freshwater ecosystems. Harmful Algae 91, 101590. https://doi.org/10.1016/j.hal.2019.03.008 (2020). 
15. D'Silva, M. S., Anil, A. C., Naik, R. K. \& D'Costa, P. M. Algal blooms: a perspective from the coasts of India. Nat. Hazards 63, 1225-1253 (2012).

16. Gomes, H. D. R. et al. Influence of light availability and prey type on the growth and photo-physiological rates of the mixotrophNoctilucascintillans. Front. Mar. Sci. 5, 374 (2018).

17. Harrison, P. J. et al. Geographical distribution of red and green Noctiluca scintillans. Chin. J. Oceanol. Limnol. 29, 807-831 (2011).

18. Gomes, H. D. R. et al. Massive outbreaks of Noctiluca scintillans blooms in the Arabian Sea due to spread of hypoxia. Nat. Commun. 5, 4862. https://doi.org/10.1038/ncomms5862 (2014).

19. Edward, J. K. P. et al. Coral reefs of Gulf of Mannar, India: signs of resilience. Proc. 12th Int. Coral Reef Symp. 18F (2012)

20. Edward, J. K. P. et al. (2018) Coral mortality in the Gulf of Mannar, southeastern India, due to bleaching caused by elevated sea temperature in 2016. Curr. Sci. 114, 1967-1972 (2018).

21. Strickland, J. D. \& Parsons, T. R. A practical handbook of seawater analysis. Fisheries Research Board of Canada, no. 167, Ottawa (1972)

22. Bauman, A. G., Burt, J. A., Feary, D. A., Marquis, E. \& Usseglio, P. Tropical harmful algal blooms: An emerging threat to coral reef communities?. Mar. Pollut. Bull. 60, 2117-2122 (2010).

23. Conley, D. J. et al. Long-term changes and impacts of hypoxia in Danish coastal waters. Ecol. Appl. 17, S165-S184 (2007).

24. Vaquer-Sunyer, R. A. Q. U. E. L. \& Duarte, C. M. Temperature effects on oxygen thresholds for hypoxia in marine benthic organisms. Glob. Change Biol. 17, 1788-1797 (2011).

25. Guzmán, H. M., Cortés, J., Glynn, P. W. \& Richmond, R. H. Coral mortality associated with dinoflagellate blooms in the eastern Pacific (Costa Rica and Panama). Mar. Ecol. Prog. Ser. 60, 299-303 (1990).

26. Zoccola, D. et al. Structural and functional analysis of coral hypoxia inducible factor. PLoS ONE 12, e0186262. https://doi. org/10.1371/journal.pone.0186262 (2017).

27. Alderdice, R. et al. Divergent expression of hypoxia response systems under deoxygenation in reef-forming corals aligns with bleaching susceptibility. Glob. Change Biol. https://doi.org/10.1111/gcb.15436 (2020).

28. Smith, S. V. The HoutmanAbrolhos Islands: carbon metabolism of coral reefs at high latitude. Limnol. Oceanogr. 26, 612-621 (1981).

29. Blakeway, D. Hypoxia shapes coral reefs. PeerJ 6, e26794v1. https://doi.org/10.7287/peerj.preprints.26794v1 (2018).

30. McManus, J. W. \& Polsenberg, J. F. Coral-algal phase shifts on coral reefs: ecological and environmental aspects. Prog. Oceanogr. 60, 263-279 (2004).

31. Raj, K. D. \& Edward, J. K. P. Observations on the reproduction of Acropora corals along the Tuticorin coast of the Gulf of MannarSoutheastern India. Indian J. Mar. Sci. 39, 219-226 (2010).

32. Raj, K. D., Mathews, G. \& Kumar, P. D. Tiger cowrie Cypraea tigris feeds on coral-competing sponge Rhabdastrella globostellata in an Acropora dominated reef of Gulf of Mannar, India. Mar. Freshw. Behav. Physiol. 52, 101-105 (2019).

\title{
Acknowledgement
}

The authors are thankful to the Ministry of Environment, Forests and Climate Change, Government of India (GOI) under National Adaptation Fund for Climate Change and Science and Engineering Research Board (SERB), Department of Science and Technology, GOI for funding support; to the Chief Wildlife Warden, Tamil Nadu Forest Department and Wildlife Warden, Gulf of Mannar Marine National Park, Government of Tamil Nadu for research permissions; and to the Suganthi Devadason Marine Research Institute for logistical support.

\section{Author contributions}

K.D.R., D.O., J.K.P.-design, writing and analysis. K.D.R., G.M., R.L.L., M.S., P.D., A.A., T.K.A.-field data collection and documentation.

\section{Competing interests}

The authors declare no competing interests.

\section{Additional information}

Supplementary Information The online version contains supplementary material available at https:/doi. org/10.1038/s41598-020-79152-x.

Correspondence and requests for materials should be addressed to K.D.R.

Reprints and permissions information is available at www.nature.com/reprints.

Publisher's note Springer Nature remains neutral with regard to jurisdictional claims in published maps and institutional affiliations.

\begin{abstract}
(c) (i) Open Access This article is licensed under a Creative Commons Attribution 4.0 International cc) License, which permits use, sharing, adaptation, distribution and reproduction in any medium or format, as long as you give appropriate credit to the original author(s) and the source, provide a link to the Creative Commons licence, and indicate if changes were made. The images or other third party material in this article are included in the article's Creative Commons licence, unless indicated otherwise in a credit line to the material. If material is not included in the article's Creative Commons licence and your intended use is not permitted by statutory regulation or exceeds the permitted use, you will need to obtain permission directly from the copyright holder. To view a copy of this licence, visit http://creativecommons.org/licenses/by/4.0/.
\end{abstract}

(C) The Author(s) 2020 